\title{
Blessed by the Lord: A Visual Portrait of a Jumli Pentecostal Congregation.
}

\author{
Samuele Poletti
}

\begin{abstract}
Many Christian converts in the Sinja Valley
of Jumla, northwest Nepal, reveal that they

have been struck by the Bible because it referenced real events, especially miraculous cases of healing. These miraculous events provide tangible 'evidence' of God's power that somewhat replicate the expectations that people nurture with respect to the Hindu deities. In such way, miracles play an especially crucial role in supporting the conversion of women and youngsters living in large families, who, partaking as veritable protagonists in Biblical events, are turned into the as quintessentially Christian subjects of a conversion narrative that helps substantiating their radical decision vis-à-vis the rest of their family.
\end{abstract}

Keywords: Religion; Conversion; Pentecostal Christianity;

Selfhood; Jumla 
One of the striking aspects about Christianity in Nepal is that Nepali people appear to convert rather spontaneously, without the need for much proselytising effort (Fricke 2008: 36; Gibson 2017b: 96). In the Sinja Valley of Jumla, northwest Nepal, oftentimes people turn to Christianity after persistent failure in healing from a physical ailment. The local incarnated deities (Khas. masțo) require onerous oblations to intervene in people's affairs through their selected mediums (Khas. dhāmī). Yet, this does not always bring about the desired effects. The problem, according to the local Christians, is that Hindus try to wash away their evils sacrificing animals. These offerings are simply eaten by their greedy gods, they say, with no benefits. For such reasons, Christian converts throughout Nepal tend to describe the relationship with the Hindu gods as exploitative (Gibson 2017a: 765; 2017b: 54). Jesus's greater power is ascribed to the fact that instead of asking for sacrifices he immolated himself for the salvation of humankind. This is why worshipping Christ is considered by converts to be much more effective.

My study of conversions to Pentecostal Christianity in Sinja has revealed that what has led many to convert are miraculous cases of healing, which somewhat replicate the expectations that people nurture with respect to the Hindu deities. These "power encounters" with the Christian God, Robert Sears observed, are a fundamental catalyst for the growth of Evangelical churches throughout the country (2018: 188). In a religious reality in which the deities are very actively involved in shaping people's lives (Poletti 2016, 2018, 2020), for Christianity to succeed Jesus needs to acquire a competing role, manifested through miracles. A miraculous improvement of one's lot is indeed how people tend to describe the great change that Christianity brought to their lives-a drastic rupture with prior conditions that characterizes Evangelical conversion narratives worldwide (Fricke 2008: 42-46; Gibson 2017a: 775; Ripert 2008: 73; Stromberg 1993). Providing tangible 'evidence' of God's power, miraculous events play an especially crucial role in supporting the conversion of women and youngsters living in large families, those people who enjoy a lesser degree of independence within Nepal's social structure, substantiating their radical decision vis-à-vis the rest of their family. These miracles tend to feature a domino effect, oftentimes leading, after a certain period of time, to the conversion of an entire kin group.

Nonetheless, miracles are something more than just a sign of God's love. Through their happening, the distant truth of the Bible can manifest in real life, overlapping with it. For Pentecostal Christians, in fact, the Bible does not tell about events that have and will happen at some other time. The scriptures narrate a story that keeps happening, over and over, in people's lives. Many a Christian I met in Sinja spoke to having been struck by the Bible precisely because it referenced real events. Their knowledge of the scriptures is actually what allows them to discern the happening of miracles: events that replicate in their life what is written in the Bible, usually inspiring cases of healing. This was, for instance, the case of the miraculous resurrection of some children, which actualized, in people's lived experience, Jesus's overcoming of death. In so doing, the miracles of their putative resurrection transfigured the world in a manifestation of the Word, which overlapped in a unique reality. "Previously, when we heard of people who died and came back to life again," said one of the children's mother, referring to Christ's resurrection, "we thought they were only mocking us." "But when this happened in my life, then I believed it was true." Events like these spark interest in the Holy text, the knowledge of which allows people to identify, in turn, new miraculous occurrences taking place in their lives, in a sort of hermeneutic circle. This appears to be how converts in Sinja cope with what Matthew Engelke calls the "problem of presence" (2007: 9). Namely, the necessity to make sense of certain aspects of their lives so as to fashion their relationship with God.

The attempt to participate in the eternal Truth of scriptural events is a documented hermeneutic activity among Pentecostal Christians (Bielo 2008: 3-5; Engelke 2007: 7; Haynes 2020: 59). Thus, in a forthcoming publication (Poletti forthcoming a), I propose to envisage the miracles I have come across in Sinja as the products of specific Pentecostal technologies of the imagination that manifest, in the concrete reality of the converts' lives, the veracity of the Word of God. In and through these miracles, the Bible relentlessly manifests the truth of the Word in the world by continually occurring in everyday life, becoming thus part of people's personal histories. Actually, the happening of miracles is not limited to the time of conversion. These may happen even years after it, as if to regularly reaffirm the rightness of their choice. Partaking as veritable protagonists in Biblical events, this sets converts up as quintessentially Christian subjects, disclosing another aspect still of the transformation of selfhood currently going through in Sinjali society (Poletti forthcoming a; also 2021). 


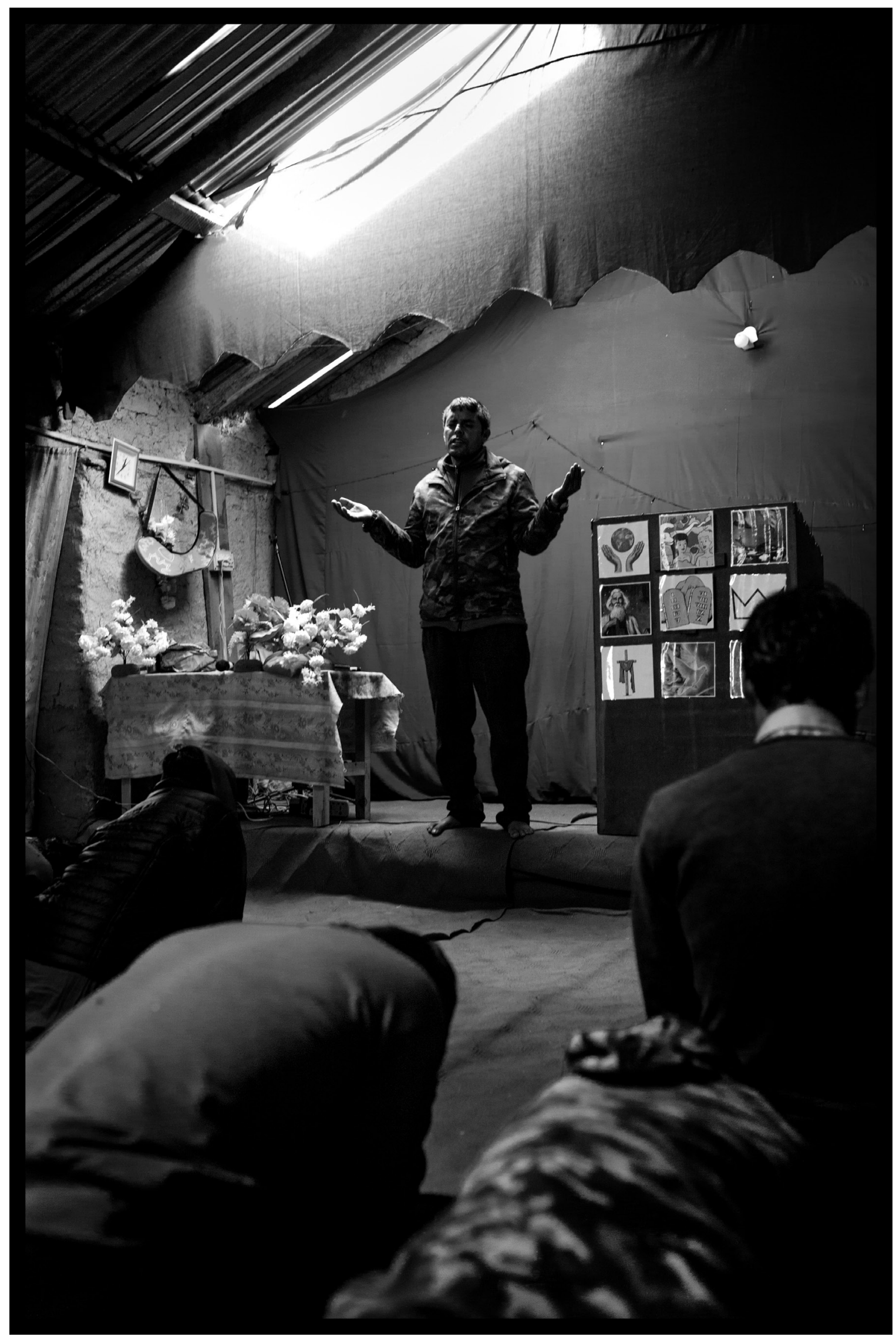

Figure 1: One of the hallmarks of Pentecostalism is the ever-present possibility of being blessed by miracles and by the gifts of the Holy Spirit. 


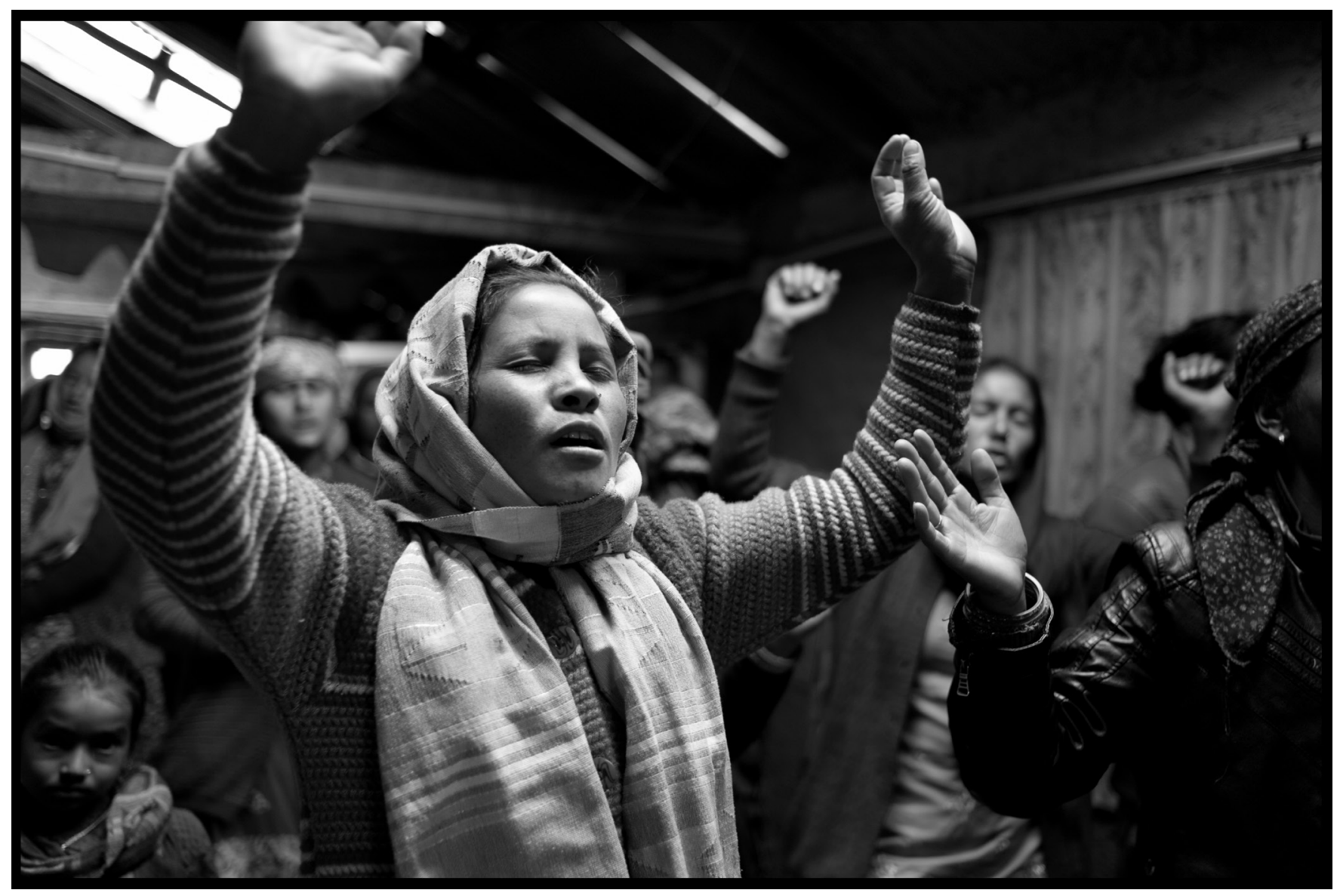

Figure 2: A recurrent theme highlighted by the converts I met is that, contrary to the other deities that they had previously known, in Christianity they have finally found a God that really listens to their prayers and who is actually willing to help them, performing miracles to solve their issues. 


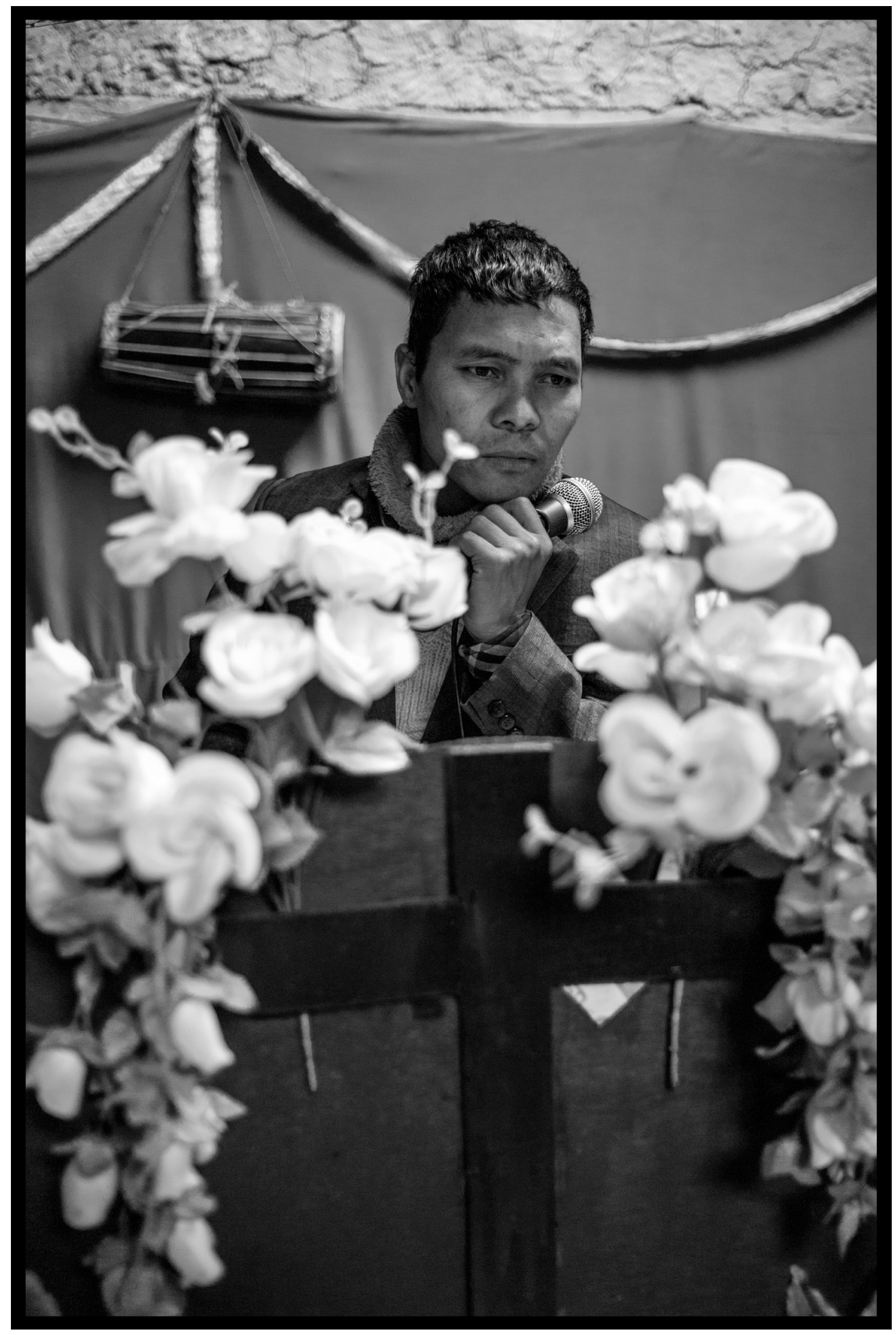

Figure 3: At the church, believers are encouraged to share their personal stories of miraculous healing with the rest of the community. This serves to illustrate Jesus's greater power over other deities and over Western medicine. At the end of one such testimony, a pastor once asked: “Who is bigger, Jesus or the doctors?" "Jesus!" the crowd shouted enthusiastically in chorus. 


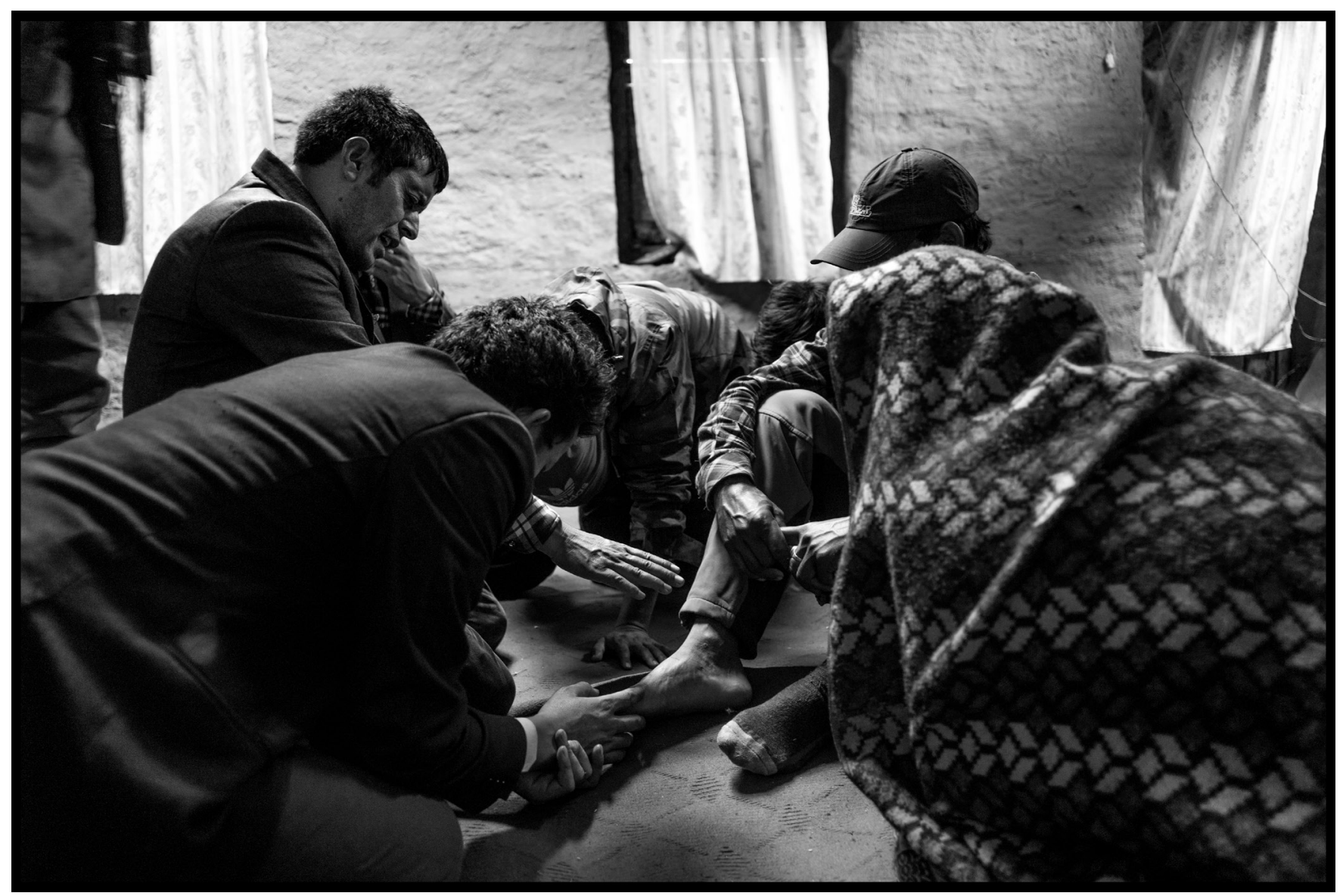

Figure 4: Believers praying over an aching foot. Asking for the Lord's blessing is common practice among Sinjali Pentecostals. 


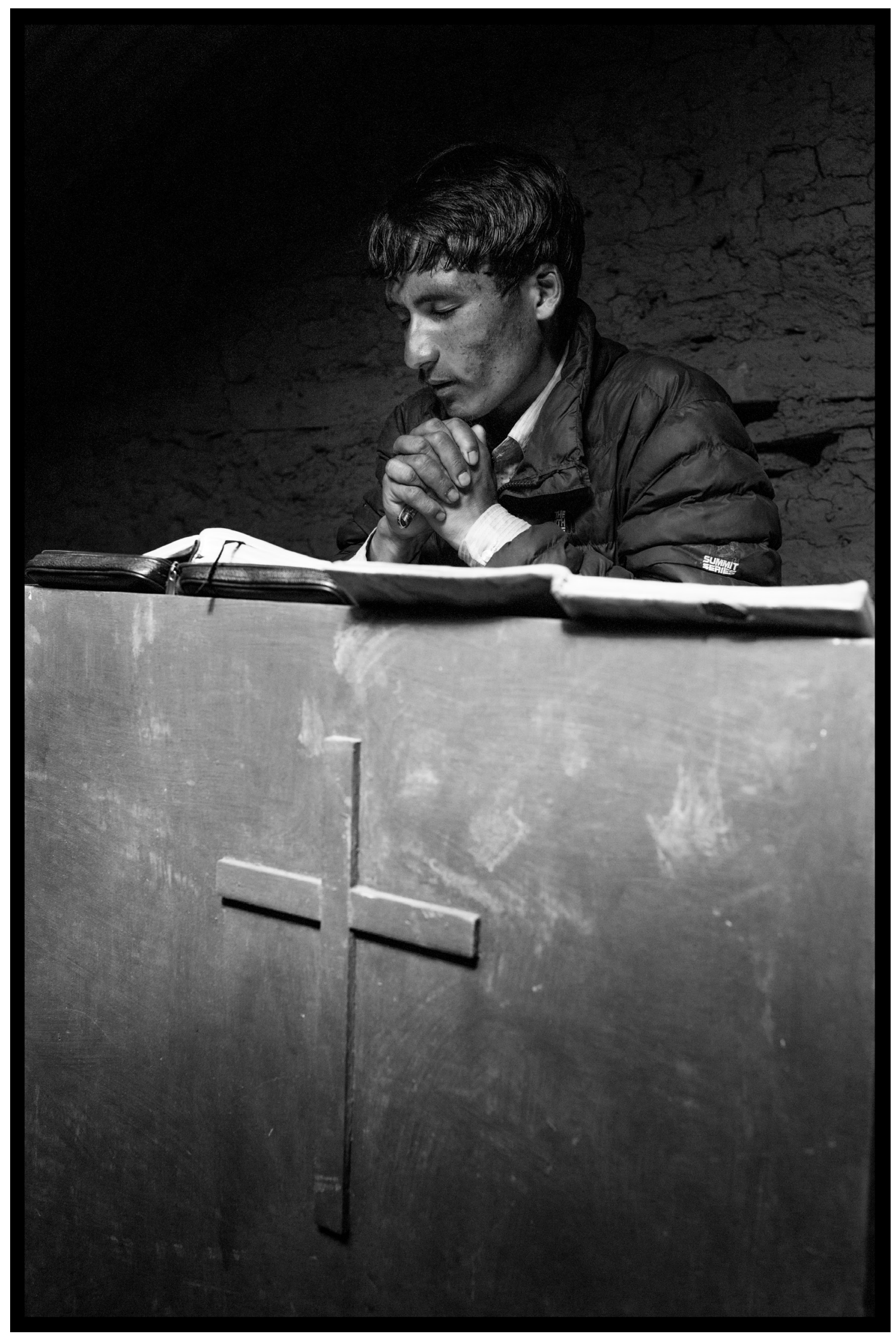

Figure 5: The healing properties that converts ascribe to Christianity far exceed the recovery from physical ailments. 'Healing' should be understood in the much broader sense of a general feeling of rediscovered existential peacefulness that supersedes a difficult situation. 


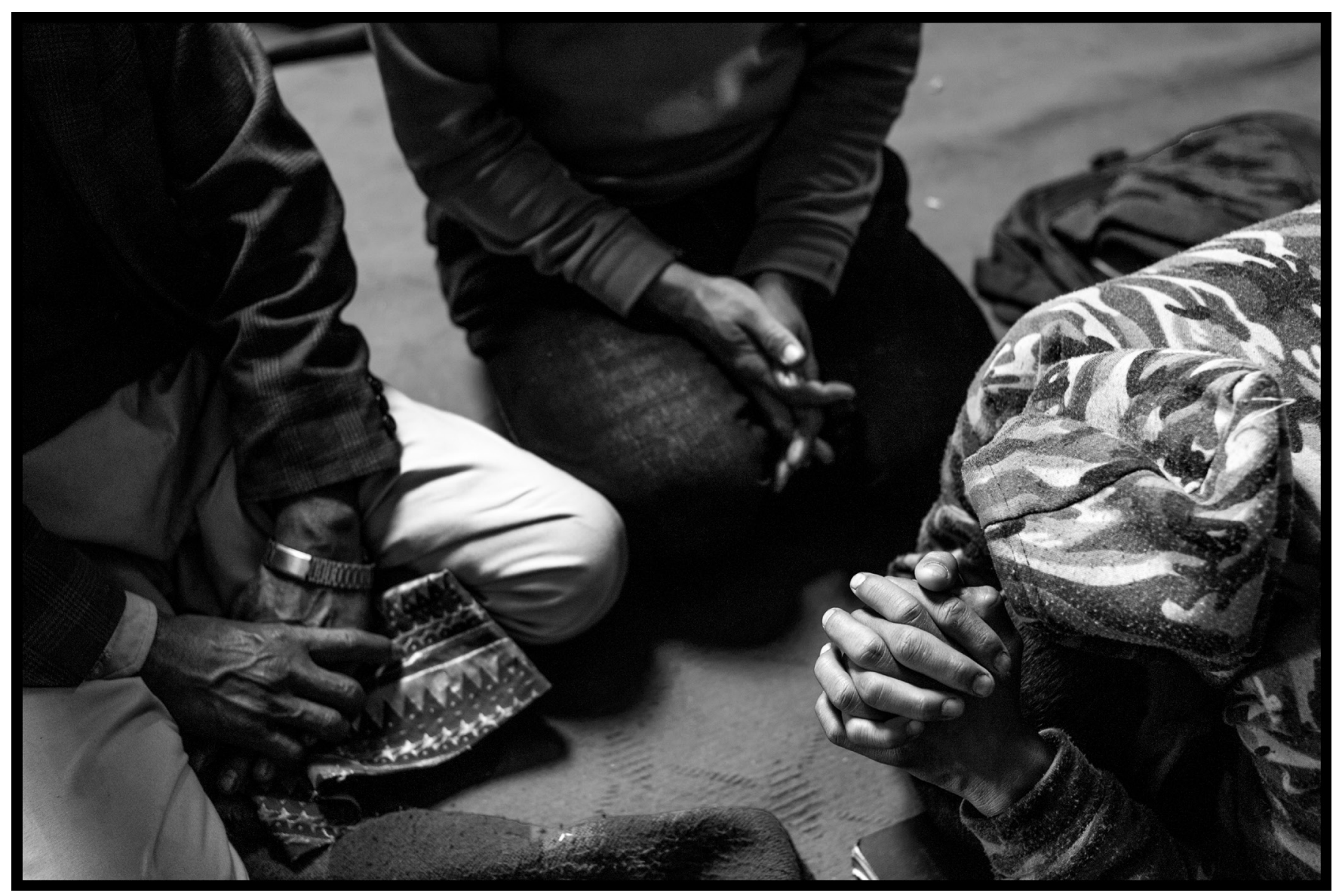

Figure 6: What makes Christianity appealing in the eyes of many is a God-and a community of believers in that God-that accepts people unconditionally and loves them for what they are, not for what they are supposed to be. Conversion, in other terms, is based on a promise: the promise of acceptance (Poletti, forthcoming $b$ ). 


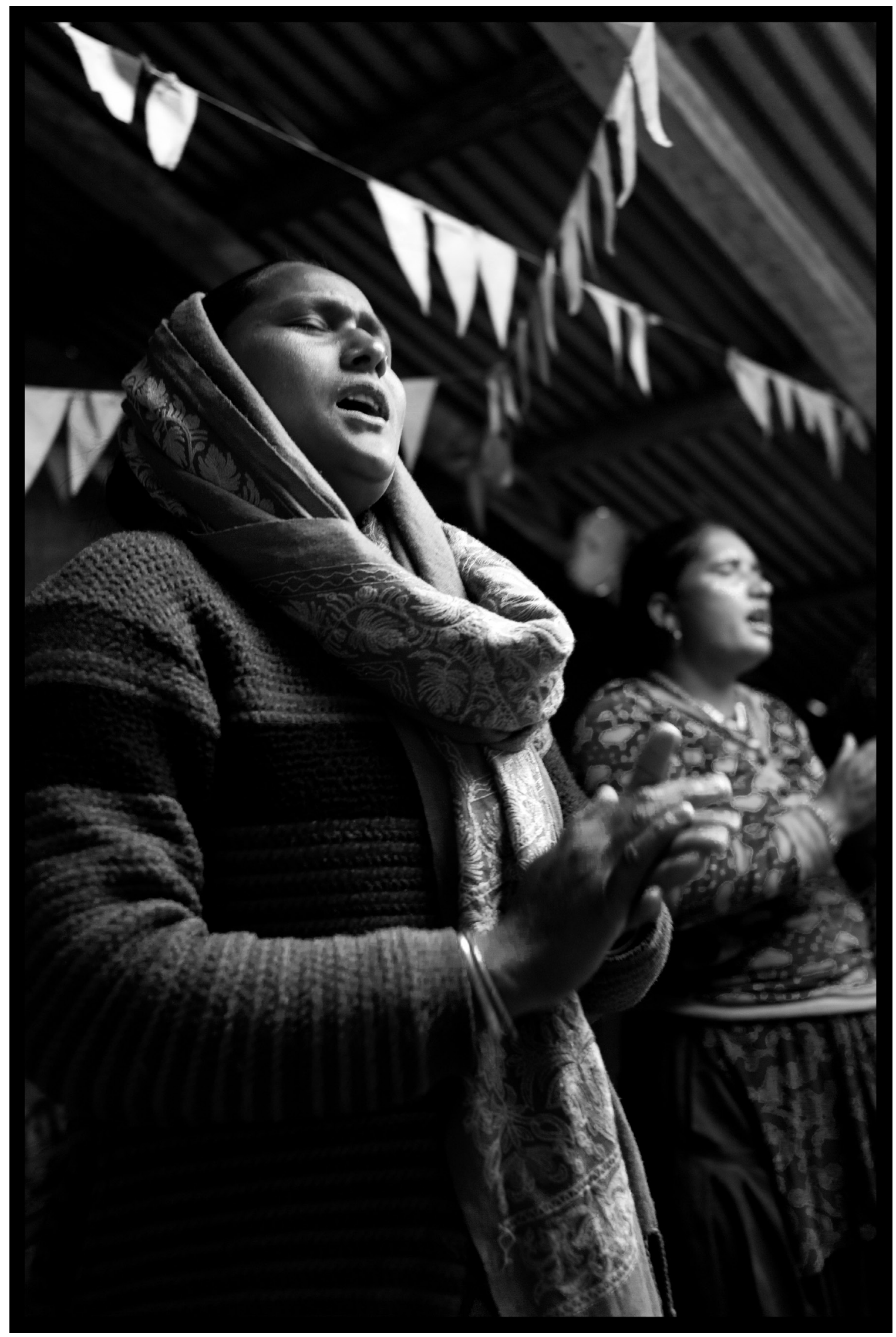

Figure 7: Although Christianity cannot be said to promote gender equality in Nepal, women outnumber men in Nepali churches. 


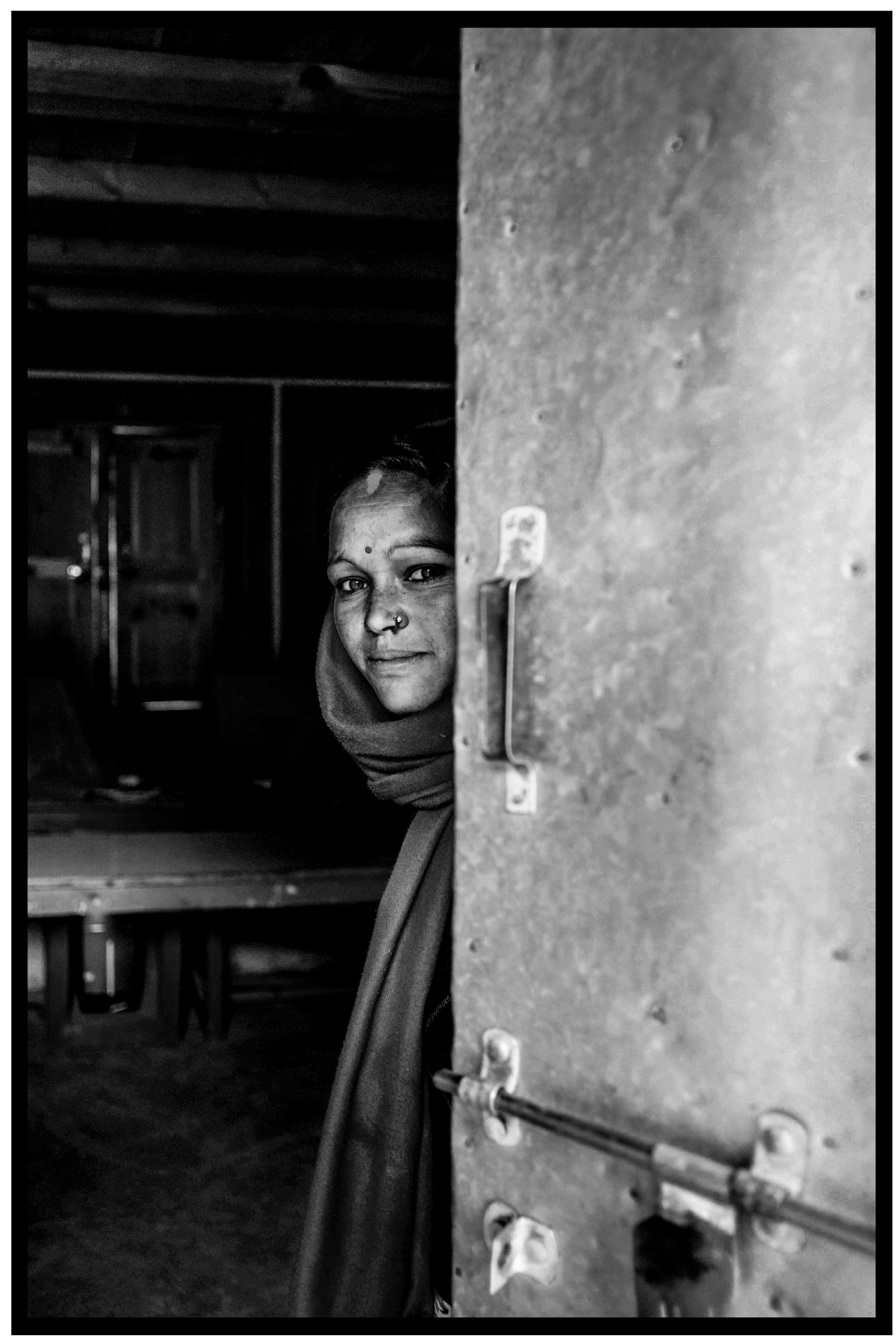

Figure 8: For people in structurally unprivileged positions in Nepal, like women and the young, it would be very difficult to convert without the support of their family. Miracles come hence in support of their conversion, providing 'evidence' that validate this choice. 


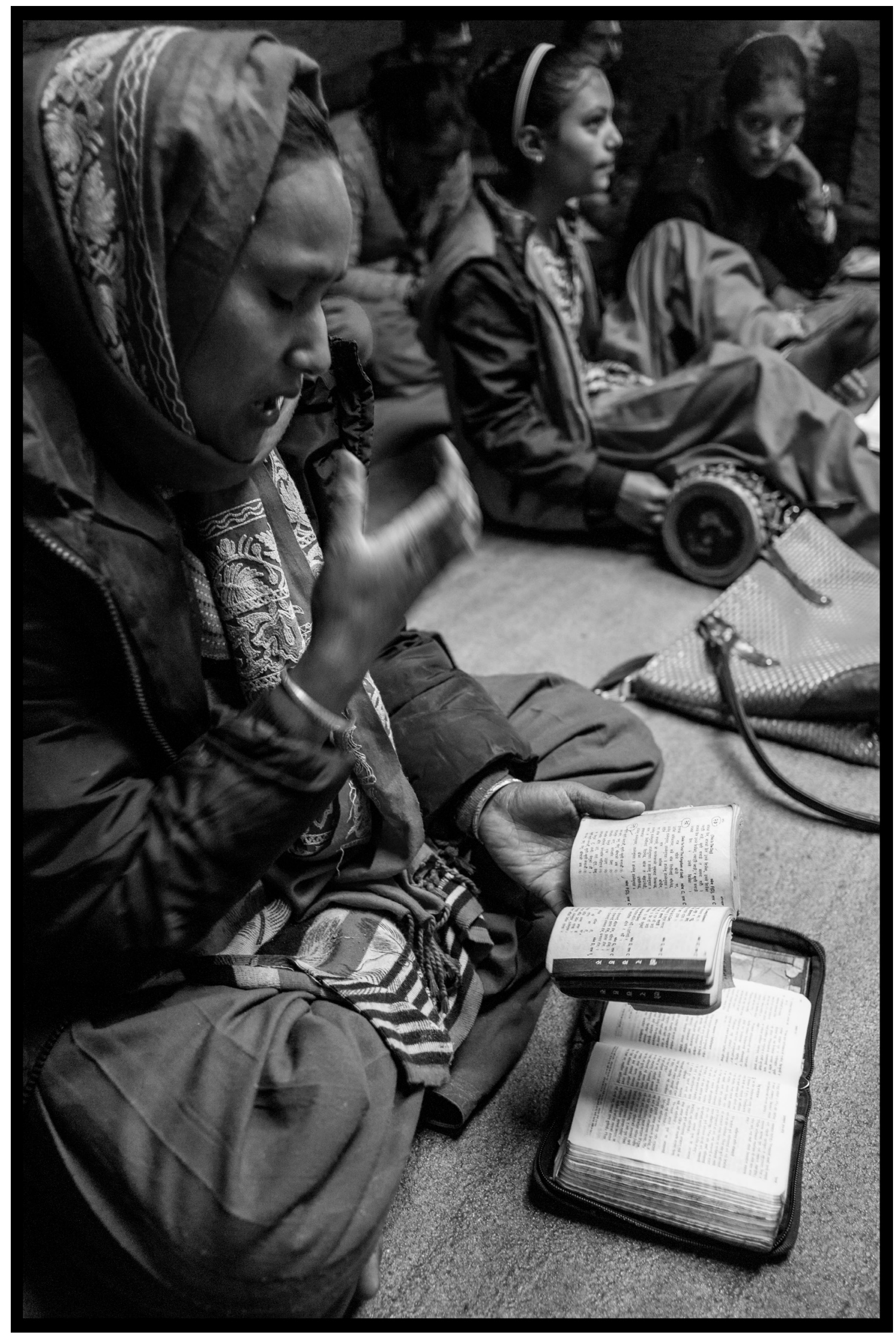

Figure 9: "I went to many temples, but only in the Bible I have found God." This is a recurrent expression to be heard among Sinjali Christians. Reading the Bible is conceived as an indispensable diet of the spirit (Nep. ātmā ko khāna), which nourishes the soul just as food does to the body. 


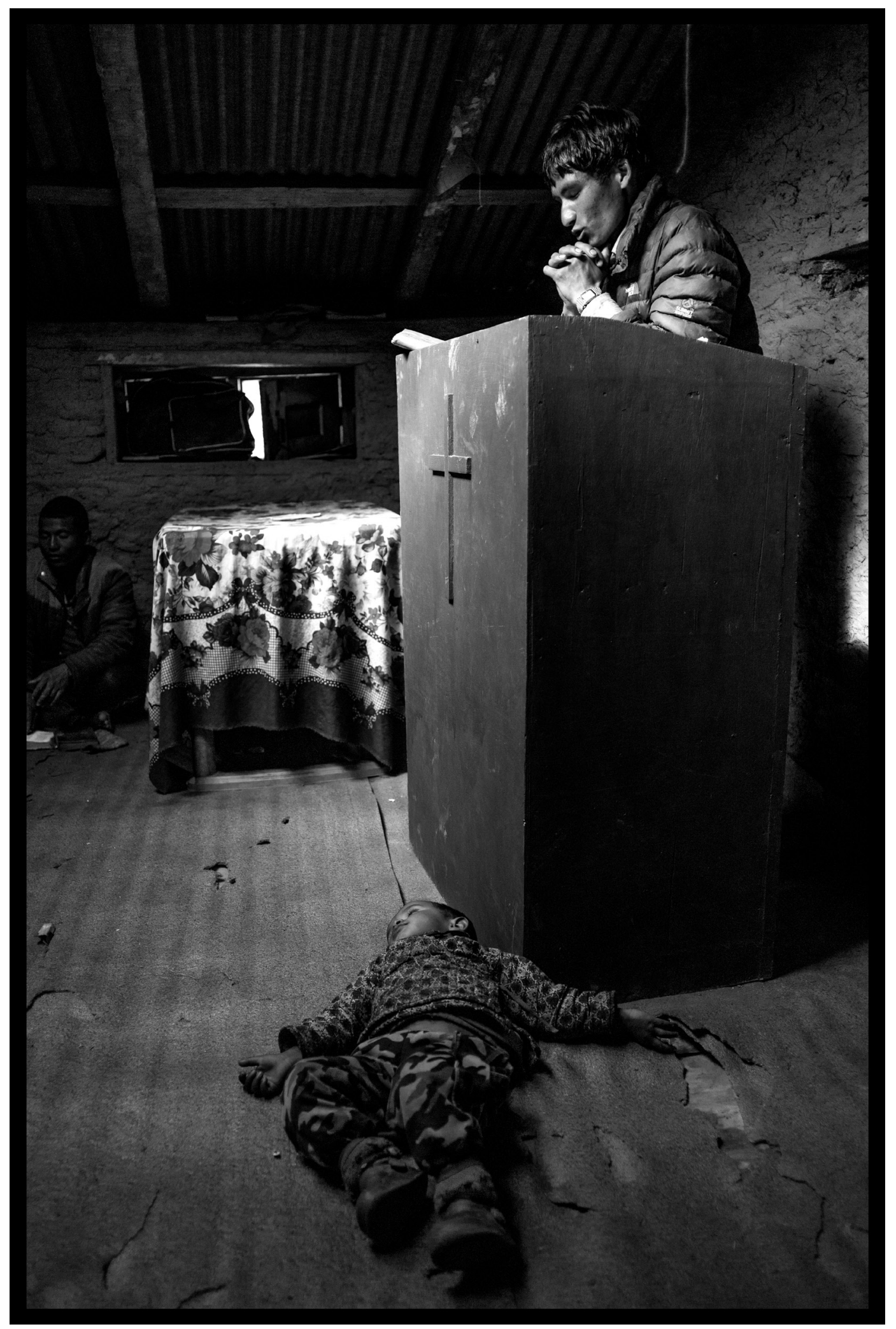

Figure 10: During Saturday service, great emphasis is put on tales of miraculous efficacy found in the Bible, such as Jesus walking on water or multiplying loaves and fishes. However, for the local Christians, what is narrated in the scriptures is a story that is happening here and now in their lives. One of the best examples of that is the story of a child who allegedly died after having eaten a wild fruit that had been poisoned by the Devil, and who was later resuscitated by God-a story that merges narrative elements of the Genesis (i.e., the story of Eve and the Fall of mankind), and of the New Testament (i.e., Jesus's victory over death and the resurrection of the dead promised upon his second coming). Despite the allegorical meaning, though, the toddler in this image was simply playing. 


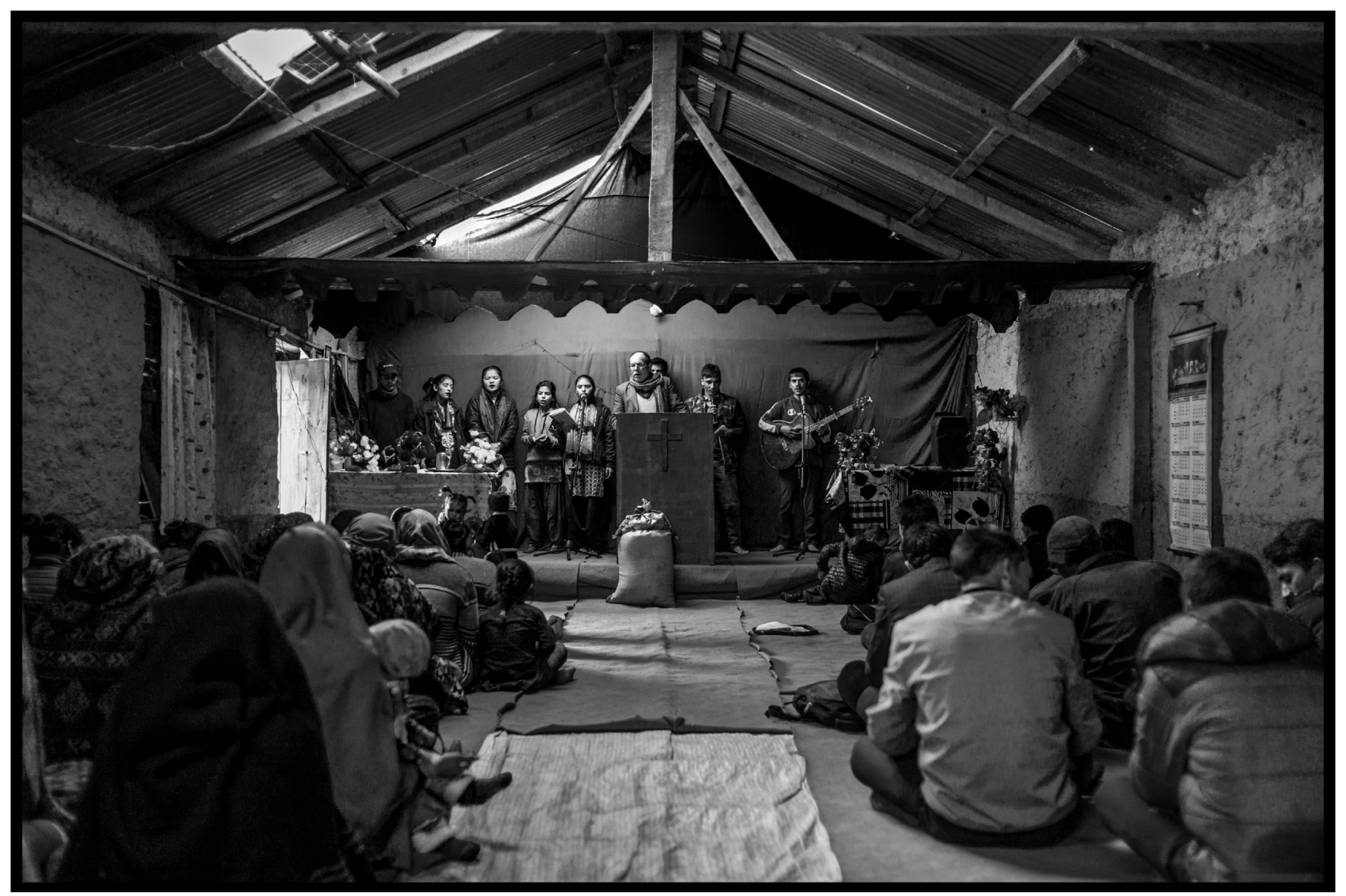

Figure 11: As lan Gibson rightly observed: "What the church community does is to provide a context in which these two things-personal experience and Biblical narratives-can come together" (Gibson 2017b: 219). In 2019, the Evangelical churches in Sinja were four, and a few others could be found further north, in Mugu. 


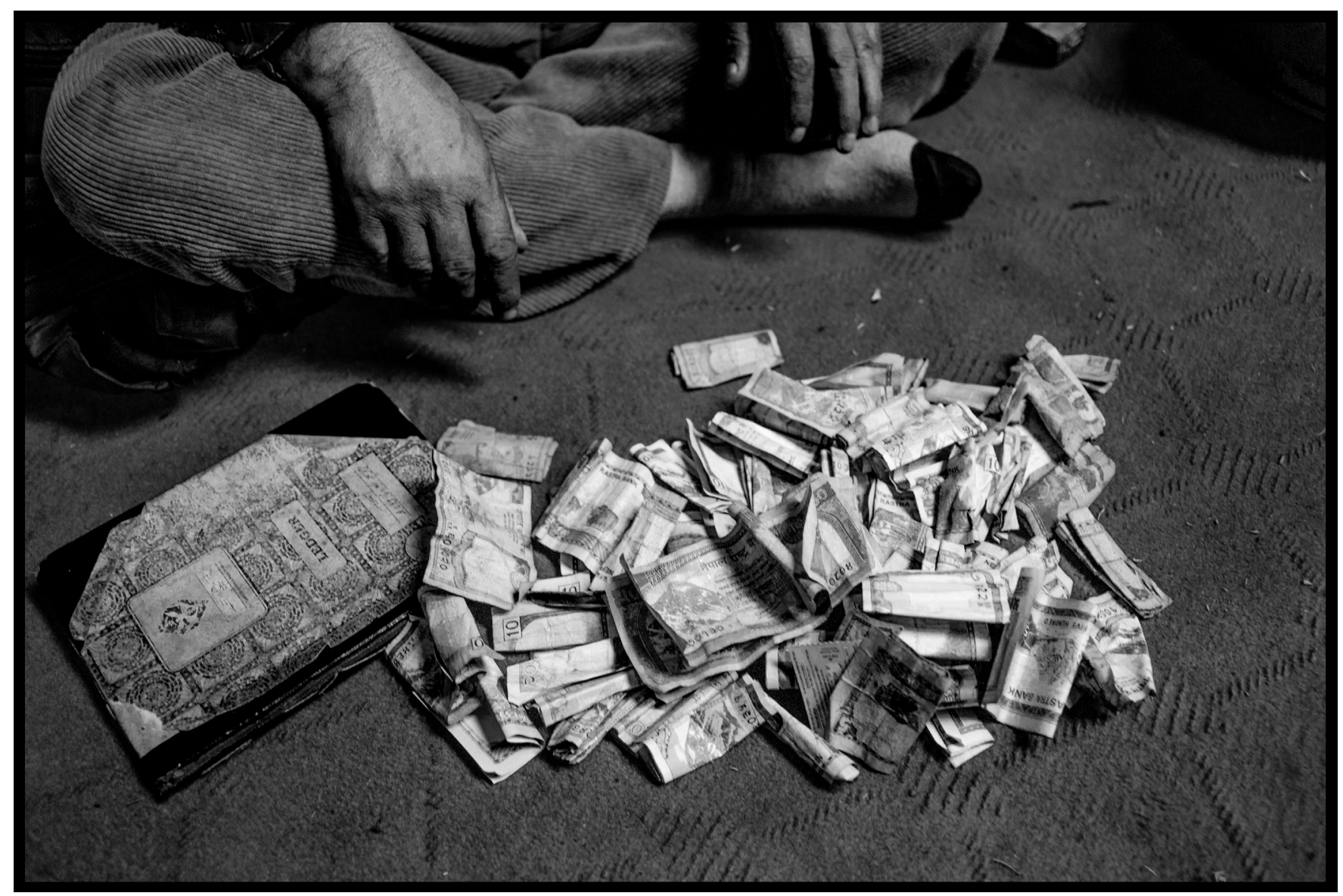

Figure 12: For conversion to be considered fully accomplished, people have to receive baptism, which is usually officiated in the water of the river. After that, people are expected to devolve $10 \%$ of their income or harvest to the Church, which enshrines full membership to the congregation. This money fuels the church's activities, providing funds that are used for the organization of festivals or to help people in need. 
Samuele Poletti was awarded his Ph.D. in Social Anthropology from the University of Edinburgh in 2019, with a thesis entitled: "In the Shadows of Death: An Existential Approach to Mortality in the Sinja Valley of Western Nepal." His doctoral research focused on the perception(s) of death in the Sinja Valley of Jumla District, northwest Nepal, and how this may shed light upon the ways in which people make sense of existence. Samuele is now a postdoctoral fellow at the Laboratoire d'ethnologie et de sociologie comparative (LESC) at Université Paris Nanterre, where he is currently working on a research project concerning the existential repercussions of conversion on the experience of personhood among Pentecostal Christian converts in Sinja, funded by the Swiss National Science Foundation (SNSF). poletti.samuele@gmail.com | www.samuelepoletti.com

\section{References}

Bielo, James S. 2008. "On the Failure of 'Meaning': Bible Reading in the Anthropology of Christianity." Culture and Religion 9 (1): 1-21.

Engelke, Matthew. 2007. A Problem of Presence: Beyond Scripture in an African Church. Berkeley; Los Angeles; London: University of California Press.

Fricke, Tom. 2008. "Tamang Conversions: Culture, Politics, and the Christian Conversion Narrative in Nepal." Contributions to Nepalese Studies 35 (1): 35-62.

Gibson, Ian. 2017a. "Pentecostal Peacefulness: Virtue Ethics and the Reception of Theology in Nepal." Journal of the Royal Anthropological Institute 23 (4): 765-782

2017b. Suffering and Hope: Christianity and Ethics among the Newars of Bhaktapur. Kathmandu: Ekta Books.
Haynes, Naomi. 2020. “The Expansive Present: A New Model of Christian Time." Current Anthropology 61 (1): 57-76.

Poletti, Samuele. 2016. "Wanderings of a Spirit: Making Sense of an Untimely Death in the Sinja Valley of Jumla." Studies in Nepali History and Society 21 (2): 251-282.

2018. "Obscure Existential Narratives: Predetermination and Freedom in Nepalese Horoscopic Knowledge." HIMALAYA 38 (1): 55-67.

2020. "The Good, the Dead and the Other: Chronicles of a Nepali Phantasmicide." Ethos 48 (3): 271-294.

2021. "Loving Fathers and Deferential Sons: Hermeneutic Respect and the Controversies of Empathy in Nepal." Ethnos. https://doi.org/10.1080/00141844.2021.18 78252

_ forthcoming a. "Miracles Matter and the Matter of Miracles: The Miraculous Reshaping of World and Self among Nepali Pentecostal Christians."

forthcoming b. "Failures of Being: The Christian Promise of Acceptance in Nepal."

Ripert, Blandine. 2008. "Christianisme et Pouvoirs Locaux Dans Une Vallée Tamang Du Népal Central / Christianity and Local Powers in a Tamang Valley of Central Nepal." Archives de Sciences Sociales Des Religions 99 (1): 69-86.

Sears, Robert E. 2018. "Dreams and Christian Conversion: Gleanings from a Pentecostal Church Context in Nepal." Mission Studies 35 (2): 183-203.

Stromberg, Peter G. 1993. Language and Self-Transformation: A Study of the Christian Conversion Narrative. Cambridge: University Press. 